WE ARE NOT BORN SUBMISSIVE 



\section{We Are Not}

\section{Born Submissive}

\section{How Patriarchy}

Shapes Women's

Lives

Manon Garcia 
English language copyright $\odot 2021$ by Princeton University Press

Originally published as On ne naît pas soumise, on le devient

(c) Climats, department of Flammarion, 2018

Requests for permission to reproduce material from this work

should be sent to permissions@press.princeton.edu

Published by Princeton University Press

41 William Street, Princeton, New Jersey 08540

6 Oxford Street, Woodstock, Oxfordshire OX20 1TR

press.princeton.edu

All Rights Reserved

Library of Congress Cataloging-in-Publication Data

Names: Garcia, Manon, 1985- author.

Title: We are not born submissive : how patriarchy shapes women's lives /

Manon Garcia.

Other titles: On ne naît pas soumise, on le devient. English

Description: Princeton : Princeton University Press, [2021] | "Originally

published as On ne nait pas soumise on le devient $\odot$ Climats, department of

Flammarion, 2018." | Includes bibliographical references and index.

Identifiers: LCCN 2020035185 (print) | LCCN 2020035186 (ebook) |

ISBN 9780691201825 (hardcover) | ISBN 9780691212623 (ebook)

Subjects: LCSH: Women-Psychology. | Feminism. | Dominance (Psychology) |

Submissiveness. | Sexual dominance and submission. | Man-woman relationships.

Classification: LCC HQ1208 .G2713 (print) | LCC HQ1208 (ebook) |

DDC 155.3/33-dc23

LC record available at https://lccn.loc.gov/2020035185

LC ebook record available at https://lccn.loc.gov/2020035186

British Library Cataloging-in-Publication Data is available

Editorial: Matt Rohal

Production Editorial: Kathleen Cioffi

Jacket Design: Sara Pinsonault

Production: Erin Suydam

Publicity: Maria Whelan and Amy Stewart

Jacket image by urfinguss / iStock

This book has been composed in Adobe Text and Gotham

Printed on acid-free paper. $\infty$

Printed in the United States of America

10988765543221 
To Esther, Eve, and Salomé 

Feminist books are generally a prospective memory of a movement which constantly needs to be taken up again; those of Mary Wollstonecraft and Simone de Beauvoir are also excellent philosophy books and should be read as such. Because books by women are all sectioned off under a special heading (by women, about women, for women), half their potential readers are deprived of solid reading matter.

-MICHÈLE LE DGUFF, HIPPARCHIA'S CHOICE

One of the most important questions confronting all feminist theorists is why women, who are, after all, a majority in most populations, so often seem to submit to or even collude with their own subordination. At its simplest, the question is: why are not all women feminists? -ALISON JAGGAR, FEMINIST POLITICS AND HUMAN NATURE 
